\title{
The COURSE towards STATE-REGULATED ECONOMY in LITHUANIA in 1939-1940
}

\author{
Gediminas VASKELA \\ Lithuanian Institute of History
}

After the loss of the Klaipeda Region (March 1939) and the start of World War II (September 1939), Lithuania was obliged to take measures to meet the newly developing difficult situation. Some organizational measures had already been taken in the spring and summer of 1939 to regulate the economic life of the country - the introduction of stricter control of currency operations, and the establishment of the Board of National Economy and of the Energy Committee. In the autumn of 1939 and the spring of 1940 new tendencies became quite evident in the management of the Lithuanian national economy.

\section{New Directions in Economic Policy}

The great powers had introduced administrative forms of centralized economic regulation during World War One. In the '20s and '30s questions concerning the state system, the structure and order of society and the economy were discussed widely in many countries. Attempts were made to look for ways out of economic crises, depressions, class and social contradictions. The world was on the way towards a state-regulated economy.

In Lithuania the economic views of the Nationalist Party acquired their definite shape during the general economic crisis, and the state had to resort to extraordinary measures to save the economy. At that time the idea of active state-participation in the contry's economic and social life became firmly established and the concept of the corporative state was actively propagated.

Having learned a lesson concerning the social and economic effectiveness of the regulatory role of the state in the period of a crisis, the Government turned to a more energetic management of the economy. Lithuanian businessmen and economists, who by that time had acquired some experience, began to demand state support in competition with the businessmen of other nationalities. On the part of specialists there was also much dissatisfaction with the inadequate development of Lithuanian industry and other branches of economy and with the insufficient activity of the authorities.

However, by the end of the '30s and the start of World War II, 
the Government was engaged in debating the situation (and letting others do the same), rather than in taking practical steps towards strengthening the regulatory function of the state. In short, Lithuanian economists and politicians did not take any great interest in pure economic theory. No doubt, it was impossible to ignore the tendencies of change in world economics and their theoretical background, in particular in neighbouring countries. In pre-war Lithuania the development of economic thought was influenced largely by the German and Austrian economic schools and, to a lesser degree, by theories current in Great Britain. That was understandable taking into account both the geographical proximity of the former countries and a number of salient peculiarities of the Lithuanian economy and political system.

President Smetona and the Nationalists as a party favoured Mussolini's doctrine of corporate economy, advocating the priority of state interests: all the social classes and strata must submit to the state and the interests of the state must be superior to individual and group interests. Nevertheless, in Lithuania there were no attempts to introduce strict control of the economy and its subjects. On the other hand, the corporate order, quite successfully functioning in Italy and to some degree imitated in Lithuania, could be adopted given certain preconditions - a more advanced industry, a more numerous working class and a stronger ruling party.

Therefore, in Lithuania the prevalent view was that rigorous control of economic matters was not necessary and even harmful, despite the attitude of the Nationalists that each branch of economy had to serve the interests of the nation rather than those of the individual capitalist. Even the managers of state enterprises were given quite a free hand in Lithuania. Control of state and especially private enterprises was exercised indirectly, by regulating customs' duties and prices. Later on after World War II began trends of economic centralization and autocracy became more noticeable.

Conservative economic views were shared both by the Nationalists and executives or specialists, belonging to other political parties. All of them were intent on spending less than was gained, on adhering to the course of 'strong currency', on being cautious in respect to innovation, in short, they pursued a prudent and circumspect policy. The estimate of the economic situation was always realistic, its scale being somewhat provincially Lithuanian. Risky and less concrete undertakings were avoided, although given of luck they might have brought succeeded.

In the 1930s, however, the dominat view was that the government had to anticipate and programme the country's economic development, co-ordinate and influence the activities of state, private and mixed enterprises. That kind of perception of the state's role and cor- 
responding economic policy definitely made their mark on ownership relations, leading to the increase in the share of the state property.'

In this context the concrete historical situation should be taken into account. After the re-establishment of independence, Lithuania lacked both capital and capable business managers. Waiting for the private sector to promote economic growth was out of the question. Therefore, according to Kazys Sruoga, "our country chose two ways. Private initiative and capital were stimulated and fostered. Additionally, public state initiative and capital were channelled into the economy'?

The view which the minister of finance, Ernestas Galvanauskas expressed emotionally during discussions of the bill 'On Managing National Economy in the Extraordinary Situation' in the Seimas was similar: 'We have established large organizations, they are called co-operatives, but they are not co-operatives, they are large capitalist organizations, let us have no illusions about that. Why did we establish them? Because there were no capitalists. Where were the capitalists in $1918,1919,1920,1921,1923$ ? We were paupers ... . Finances, collected in the form of taxes, were taken from the state treasury, and these organizations were formed. ... I am not saying that this is an ideal case, God forbid, no, we were forced to do that'.

Between 1938 and 1940 economic centralization was a very topical issue in Lithuania. According to the official viewpoint despite some attempts there was no programme/plan and no body authorized to prepare such a plan. Regrettably priority was given to some spheres of economic activity without any preliminary perspective. The process of centralization was acknowledged, because some state-endorsed centres - Lietūkis, Pienocentras and Maistas - were increasing their turnovers and creating new centralizing structures. Compared with other organizations these three large companies appeared to be more active and more powerful because they enjoyed state support. Eventually their activity started to exert influence on the general economic policy of the state, sometimes even contradicting the interests of the state. In

'Algimantas Jablonskis states that prior to 1940 the portion of the Lithuanian statc and public sector was between 20 and $30 \%$, i.e., approximately corresponding to the situation in many developed Western countries after World War II, when John Maynard Keynes's doctrine was nearly universally adopted. Sec Algimantas Jablonskis. Valstybinis ckonomikos reguliavimas. Lietuvos ükis, no. 3-4, 1992, 32. Supposedly this assertion is based on Lietuva. Lietuviu enciklopedija, 2nd cd., vol. 15, Vilnius, 1990, 222; this publication, however, deals primarily with the role of trade co-operatives. In our opinion, the public sector share was slightly smaller, about $20 \%$, may be $25 \%$, but nevertheless it was very big.

${ }^{2}$ K. Sruoga. Lictuvos įmonès, kuriose dalyvauja valstybé. Vairas, no. 15-16, 1938, 917.

${ }^{3}$ E. Galvanauskas' concluding specch at the Seimas sitting on 5 April 1940, discussing the draft of the law "On Managing National Economy in the Extraordinary Situation," presented by the minister himself. LCVA, f. 923, ap. 1, b. 1114, I. 615. 
other countries spontaneous centralization had long been limited and controlled by the state. 'There can be no justification for the practice, so widespread at present with us when anybody can do anything, anybody is allowed to do whatever he thinks fit. In other words, in our country liberalism is extreme at the time when we are surrounded by the states, which are autocratic and control their economies... Once and for all the competence and the sphere of activity of each centre must be determined quite clearly and parallelism and clashes must be eliminated'. ${ }^{4}$

According to Galvanauskas, even under normal circumstances life itself makes the state interfere into certain spheres of economy and nobody questions that right and duty of the state. Only the extent of the intervention and the size of state investments into national economy can be discussed. ${ }^{5}$

The member of the Seimas and director of the Chamber of Agriculture, Stasys Jakubauskas (Jokūbauskas), stated that Lithuania had to turn to centralized commerce as other states did in acquiring commodities, which were difficult to obtain. Centralization had already been effected 100 per cent in some fields of export and import. However, there were fields where regulation was still necessary, especially with respect to prices of the domestic market, which should be kept as stable as possible. The centralization of imports and exports would contribute to the stability of prices. ${ }^{6}$

In 1939 and 1940 K. Sruoga, S. Jakubauskas and other adherents of state-regulated economy and its centralized management were supported both by the minister of finances E. Galvanauskas and the prime minister, Antanas Merkys. In the prime minister's opinion, Lithuania needed a kind of general headquarters of economy, and that idea was being put into effect under the guidance of the minister of finances. That meant the start of a new economic phase, 'a phase of direction.' We are surrounded by neighbours, whose economy is directed.".

\section{Foreign Trade}

After the loss of the Klaipeda Region restrictions were imposed on imports, especially on the so-called luxury goods, and attempts

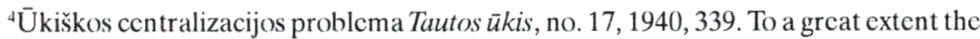
theses can be considercd a programme document of Antanas Mcrkys' government.

5The concluding specch of E. Galvanauskas at the Seimas sitting on 5 April 1940, discussing the draft of the law "On Managing National Economy," presented by the ministcr himsclf (8th ordinary session, sitting no. 178). LCVA, f. 923, ap. 1, b. 1114, I. 614.

${ }^{6}$ The speech of S. Jakubauskas on 20 April 1940 at the 7th extraordinary session of the Scimas (sitting no. 183/34), discussing the state budget of 1940.

${ }^{7}$ A. Merkis' specch at the sitting of the Scimas on 5 April 1940 (the 8th ordinary scssion, sitting no. 178). LCVA, f. 923, ap. 1, b. 1114, 1. 608. 
were made to increase exports. A special export committee was organized. Following the example of other countries, steps were taken to centralize foreign trade. The introduction of centralization and state regulation was motivated by the need to remove the mutual competition of Lithuanian businessmen in foreign markets. In the opinion of officials and economic experts that kind of competition worsened the conditions of trade contracts, and that, in its turn, meant great losses for the state. ${ }^{8}$

Doubtless, the most important thing was the radical change of commerce operations. In 1938 the trade balance of the states, with which accounts were made on a clearing basis 9 Germany, Latvia, Italy, Finland, Hungary and Greece 0 made up 28.5 per cent of the total trade turnover (29.7\% of exports and $27.3 \%$ of imports). Between January and April 1939 their position rose to $31.5 \%$ (31\% of exports and $32.1 \%$ of imports), between May and December of the same year - up to 40.4 per cent (39.6\% of exports and $41.3 \%$ of imports). During the first four months of 1940 the accounts of clearing made up 57.3 per cent of the total trade turnover $53.4 \%$ of exports and even $61.8 \%$ of imports). Unwillingly, Germany became Lithuania's main trading partner - its proportion in the general turnover of Lithuanian foreign trade rising from 25.7\% in 1938 to 53.1\% in January-May 1940 (28.1\% in January-April 1939 and 37.7\% in May-December 1939).'

When hostilities started, the parties at war began imposing blockades on each other and involving other countries in particular due to the pressure of Germany, tacitly supported by the USSR. Until 1939 the main source of foreign currency was trade with Great Britain, whose proportion in the Lithuanian foreign trade was about 34.1 per cent already in 1939 (40.5\% in export and $26.4 \%$ in import). However in 1939 and 1940 the amount of the turnover and the proportion in the trade with Great Britain were continually decreasing to 0.9 per cent of Lithuanian export into England and 3.0 per cent of import (1.9\% of the trade turnover). ${ }^{10}$

It is understandable that Lithuania could not resist Germany's demands to decrease or even abandon altogether the trade with Britain. On 24 October 1939 the director of the Economics Department of the Ministry of Foreign Affairs Jonas Norkaitis informed the minister of finances that the secretary of the German Embassy in Kaunas Ungern von Sternberg had visited him and warned that Germany was not going to tolerate the Lithuanian export of food products to Britain

${ }^{8}$ Centralizuota užsicnio prekyba. Tautos ükis, no. 59, 1939, 931.

"The cstimatc is bascd on Ekonominis biuletenis, no. 22, 1940. LCVA, f. 923, ap. 1, b. 1081, 1. 45; Ekonominis biuletenis, no. 23, 1940. LCVA, f. 923, ap. 1, b. 1081, I. 9.

"The cstimatc is made on the basis of Ekonominis biuletenis, no. 22, 1940. LCVA, f. 923, ap. 1, b. 1081, 1. 45-46; Ekonominis biuletenis, no. 23, 1940. LCVA, f. 923, ap. 1, b. 1081 , I. 9 
and would detain all Lithuanian ships carrying foodstuffs to that country. ${ }^{11}$

Lithuania was greatly interested in wider economic contacts with Great Britain. The government applied to Moscow asking for advice concerning possible further steps - in actual fact that was a request for Soviet assistance. On 5 December 1939 the representative of the USSR in Lithuania cabled to Moscow that, in the person of a highranking official of the German Ministry of Foreign Affairs, Schnurre, Berlin had 'categorically, with a hint of threat', required that Lithuania break off all commercial relations with England. Juozas Urbšys applied to him, Nikolai Pozdniakov, and indicated that the Lithuanian government would have to ask the USSR for advice, if Berlin categorically insisted on it'. ${ }^{2}$ As it could have been expected, no support came from Moscow. The following day Pozdniakov received Viacheslav Molotov's answer: 'We advise the Lithuanians to take German demands into consideration'. ${ }^{13}$

Lithuania tried to continue the dialogue with the Kremlin on that topic. On 17 December 1939 the Lithuanian envoy in Moscow Ladas Natkevičius informed Molotov that Germany requested Lithuania to sever trade relations with Britain. Natkevičius indicated that Lithuania exported about 40 per cent of all its export to Britain and thus received convertible currency. The German requirement placed Lithuania in very disadvantaged circumstances and therefore she was asking for advice. Molotov again replied that with the war going on it was virtually impossible to trade with Great Britain and again recommended Lithuania 'to take heed" 14 of German demands.

In May 1939 Germany itself offered Lithuania additional quotas to the trade treaty for oats and barley (for 2,000,000 lt.), timber $(1,200,000$ lt. $)$, pigs $(2,000,000$ lt. $)$ and flax $(600,000$ lt. $) .{ }^{15}$ At the start of the war Germany's domination of Lithuanian foreign trade was quite obvious, and this caused fear among Lithuanian economists and managers. The situation was the more alarming, because of the positive balance of trade, covered by Germany neither with convertible cur-

"J. Norkaitis' report of 22 November 1939 to the minister of finances on the commerce betwecn Lithuania and Germany and between Lithuania and England. LCVA, f. 383, ap. 7, b. 2148, I. 286; Regina Žcpkaitć. Vilniaus istorijos atkarpa: 1939 m. spalio 27 d. 1940) m. birželio $15 \mathrm{~d}$. Vilnius, 1990.

${ }^{12}$ The 5 December 1939 telegram of the plenipotentiary representative of the USSR in Lithuania N. Pozdniakov to the People's Commissariat of Forcign Affairs of the USSR. Kaimyno akys ir ausys. Pasaulis, no. 6, 1991, 17.

${ }^{13}$ The 6 December 1939 telegram of the Pcople's Commissar of Foreign Affairs V. Molotov to N. Pozdniakov in Lithuania. Kaimyno akys ir ausys. Pasaulis, no. 6, 1991, 18.

${ }^{14}$ A USSR People's Commissariat of Forcign Affairs official's recording of the talk betwecn L. Natkevičius and V. Molotov on 17 December 1939. Kaimyno akys ir ausys. Pasaulis, no. 6, 1991, 18.

${ }^{15} \mathrm{R}$. Žcpkaitc. Vilniaus istorijos atkarpa, 65. 
rency nor with merchandise. In December 1939 Lithuanian exports to Germany exceeded imports by 8,600,000 lt. and this imbalance was expected to rise. As Regina Žepkaite put it, "there were fears that this imbalance would grow, because Germany, conducting wars, was not in a position to export to other countries, among them to Lithuania, and was not willing to pay her debts. Assets frozen in Germany were of no use and impaired the development of Lithuanian economy'. ${ }^{16}$

Žepkaite is not quite right on this issue. True, the above-mentioned report of the Economics Department of the Ministry of Foreign Affairs referred to alarming tendencies in Lithuanian foreign trade. At the same time, the Department formulated certain principles of trade policy in the newly developing situation and proposed concrete ways for the rational solution of the problem. This document is worth a more detailed analysis, especially as in 1940 it was being put into practice.

According to the document, the forced trade turnover with Germany will be the same as that with England, Germany, Czechoslovakia and Poland taken together in pre-war years. That would constitute about 80 per cent of total foreign trade. Considering the facts that the products hitherto sent to England would go to Germany and that in 1939 the Lithuanian active balance in the trade with England was $37,700,000$ lt.., a great positive balance in the trade with Germany could be expected in future.

All that can be a starting point for the endeavours to narrow the gap between our export to Germany and the import from there in order to avoid freezing large assets. The contemporary trade treaty with Germany envisages a turn over of 60,000,000 lt. Now an increase of up to $110,000,000-120,000,000 \mathrm{lt}$. is being planned. Bearing in mind that at present there have been no restrictions for the import from Germany and our import can not equal the export, it is doubtful if practically the import could be doubled. Measures should be taken to force the issue of import. ${ }^{17}$

Imports can be divided into a) consumer goods, b) commodities and c) new investments. The import of larger amounts of consumer goods would hardly be feasible, because that is associated with the market receptivity. On the other hand, being at war, Germany could hardly supply the necessary kinds of goods. It would also be not reasonable to increase the import of consumer goods, since that would not raise the economic capacity of the country. It would suffice to make that type of import livelier by allotting $30 \mathrm{mln} .-50 \mathrm{mln}$. 1t. as a tem-

${ }^{16} \mathrm{R}$. Žcpkaitc. Vilniaus istorijos atkarpa, 65 (The author's reference to the pro memoria of the Economic Department of the Ministry of Forcign Affairs concerning the trade relations with Germany. LCVA, f. 383, ap. 9, b. 192, 1. 36-41.)

${ }^{17}$ The pro memoria of the Economic Department of the Ministry of Forcign Affairs concerning the trade rclations with Germany. LCVA, f. 383, ap. 9, b. 192, I. 36. 
porary and exclusively commercial credit, extended either by the Bank of Lithuania itself, or by some short-term credit banks. Additionally, the government would have to assume responsibility (at least for75 per cent should the war end soon), since private capital would not run such risk.

In addition to credits, there must be bodies to organize import in case ordinary trading operations would be insufficient. For that purpose special joint-stock companies should be set up. Existing trade organizations should be encouraged to accumulate stocks of necessary commodities, financed by the above-mentioned credits. One more way would be complete cancellation of import licences for German goods. If import quotas were not promptly fulfilled, appropriate branch companies could start working to deal with the situation. Thus they would perform the function of an economic regulator. ${ }^{18}$

The renewal of all the branches of national economy should be given greater attention than it had been done so far in the yearly budgets. For that purpose the interested branches of economy should draw their budgets and be given credits enabling them to make unrestricted orders. The resulting temporary deficit of the state budget could be compensated for by issuing short-term bills of the state treasury.

New investments would be the main type of the import from Germany:

1) Industrialists and craftsmen should be encouraged to develop, reconstruct and modernize their enterprises; these investments would require the minimum of state credits and would soon yield results.

2) A special modernization plan should be prepared (and endorsed by the budget) for the capital investments into national economy and corresponding departments made responsible for its realization.

3) In establishing new enterprises emphasis should be laid on the use of private capital, wherever possible. In the spheres where private initiative would be insufficient, private joint-stock companies could be set up with the help of state capital. This investment plan should envisage the establishment of industrial enterprises, necessary for the whole of Lithuania, so that it could become as soon as possible a country exporting products or at least semi-finished products rather than raw materials. The number of orders should be large enough to exploit fully the possibilities of the trade with Germany, its own export potential and not freeze the assets. ${ }^{19}$

For this commerce activity to proceed smoothly it is necessary to set up (a) a special body, responsible for the preparation of orders and (b) a corresponding financing mechanism, acting also as a regula- 
tor in case of any disproportion between Lithuanian export and its import from Germany. Priority should be given to financing investment orders. There would be no need for foreign credits, because Lithuania would import in conformity with its exports. The state, however, would be faced with the problem of paying the producers for their export products, because the means, derived from the export to Germany, would be invested in industry. ${ }^{20}$

This type of economic policy would give the country a chance to exploit the war situation to take a big step forward in creating industry to increase its economic capacity and raise the living standards without foreign loans and the danger of economic enslavement. Agricultural capacity could also be more fully exploited.

The report ends with the conclusions, related to the endeavours of avoiding the danger of freezing the assets in Germany. The following measures are recommended: supplies;

1) enforced purchases of consumer goods and laying up of their

2) increasing urgent state orders, and

3) placing large-scale investment orders.

Practically, the increase of Lithuanian exports in the first months of the war should be compensated by importing commodities for keeping in reserve and for state institutions and later - after a year or two - by importing investment values. However, the orders for the production of investment values should be placed in advance, so that they could be shipped without delay. If everything is organized in due time, it could be expected that Lithuanian assets would not be frozen in Germany. ${ }^{21}$

Even if one could describe the attitude of the Economic Department of the Ministry of Foreign Affairs toward the chances of Lithuania as over-optimistic, its staff did not lack sensible reasoning. Certain preliminary steps were made and already in 1939 some departments compiled lists of commodities to be bought in Germany in 1939-1941. The plans for investment orders were quite impressive, the total reaching over $120,000,000 \mathrm{lt}$.

The list of the Ministry of Communications comprised fuel, machines and equipment for 69,600,000 lt. (locomotives, carriages and stocks, tracks, etc. - 27,300,000 lt., 450,000 tons of coal and 50,000 tons of coke - 30,000,000 lt., preparations for the construction of the seaport of Šventoji - 3,800,000 1t., automatic telephone exchange equipment - 700,000 lt.). ${ }^{22}$

${ }^{20}$ Ibid., l. 39.

${ }^{21}$ Ibid., 1. 40.

${ }^{22}$ The list of commodities to be bought in Germany in 1939-1941. LCVA, f. 387, ap. $4 a$, b. $3183,1.5$ (coal and cokc were mcant not only for the necds of the Ministry of Communications). 
Maistas, Pienocentras and Lietūkis planned to purchase goods for 6,200,000 lt. (fuel tanks, engines, agricultural equipment, materials for barrel production, pipes for artesian wells, an elevator in the sea-port of Šventoji). Additionally provision was made for 2,500,000 lt. for the equipment of the narrow-gauge railway and for various factory equipment. ${ }^{23}$

The imports, planned for industrial needs: 20 peat machines $(1,000,000 \mathrm{lt}$.), two cement factories, each with the capacity of 75,000 tons $(4,000,000 \mathrm{lt}$.), 20 brickyards to produce $50,-60,000,000$ bricks $(1,500,000 \mathrm{lt}$.), equipment for the extension of a hardware factory $(1,000,000$ lt.), railway car works $(3,200,000$ lt. $)$, a factory of agricultural machinery $(1,000,000 \mathrm{lt}$.), two plywood factories with the capacity of 15,000 and $8,000 \mathrm{~m} 2$ (2,000,000 lt.), a sugar refinery (3,000,000 lt.), dairies $(1,400,000$ lt.), slaughterhouses, refrigerators and their equipment (1,000,000 lt.), textile mill equipment (5,000,000 lt.), 20 factories of primary flax processing $(3,300,000 \mathrm{lt}$.), factories of superphosphate (100,000 tons) and sulphuric acid (4,000,000 lt.), a factory of synthetic ammonia and soda $(1,500,000 \mathrm{lt}$.), a factory of chlorine and alkali $(1,000,000$ lt.), an iron and steel foundry $(1,000,000 \mathrm{lt}$.), a factory of industrial machinery $(1,000,000 \mathrm{lt}$.), a cellulose factory, including the equipment for the production of paper $(3,500,000 \mathrm{lt}$.); finally the debt of the power station of Skaruliai $(6,000,000$ lt.) should be mentioned. All in all, plans were made for purchasing various commodities and equipment (including the construction of factories) for 53,800,000 lt. ${ }^{24}$

The balance of the Lithuanian-German trade shows the first steps in the realization of these contracts. In May-December 1939 the monthly import from Germany was 5,400,000 lt., whereas in JanuaryApril 1940 it was 10,400,000 lt. The former positive balance made up $670,000 \mathrm{lt}$. a month, while at the beginning of 1940 it became negative and reached 1,200,000 lt. 25

Issues, related to Lithuania's industrialization plans will be discussed below. The materials analyzed so far are important in that they indicate radical changes in the foreign trade of the country, the attempts to minimize their negative effects and the efforts of the state to interfere into economy and to establish centralized control of its foreign trade and economy in general.

Discussions on Cooperation and State Joint-Stock Companies In 1939-1940 the state sector in the national economy was relatively large in all the Eastern Baltic states, actually, one of the lar-

${ }^{23}$ Ibid., 1. 5-6.

${ }^{24}$ Ibid., I. 7-8.

${ }^{25}$ The estimate is based on Ekonominis biuletenis, no. 22, 1940. LCVA, f. 923, ap. 1, b. 1081, 1. 45; Ekonominis biuletenis, no. 23, 1940. LCVA, f. 923, ap. 1, b. 1081, 1. 9. 
gest in the world (of course, excepting the Soviet Union). In Lithuania the state share in the total industrial output reached about $15 \%{ }^{26}$ and, in actual fact, the share of the social sector was even greater, because some of the industrial enterprises belonged not to the state, but to local government bodies. In 1937 the commodity turnover of the Maistas joint-stock company alone was $1.5 \%$; $69.8 \%$ of its shares belonged to the state treasury. ${ }^{27}$ In 1939 Lietūkis controlled $15.5 \%$ of the total Lithuanian export, and trade cooperatives, in which a considerable share of the capital belonged to the state, had between 20 to $25 \%$ of the total commodity turnover (in 1937 - 15.6\%). ${ }^{28}$ The state also controlled all railways, postal communications, telegraph and radio, etc., and actually all the sea transport belonged to the state as well.

On 1 January 1939 the share of the state made up 88,250,000 lt. in the assets of the 21 joint-stock companies $(86.2 \%$ of the total capital of 102,300,000 lt. of these companies). ${ }^{29}$ On 1 January 1940 the capital of 22 joint-stock companies was 105,800,000 lt., and of that sum 78,900,000 lt. (or 74.55\%) belonged to the state. ${ }^{30}$ At that time 137 joint-stock companies functioned in Lithuania and their capital was 205,400,000 lt. ${ }^{31}$ Thus, between the end of 1937 and the beginning of 1939 the proportion of the state capital slightly decreased and made up $38.4 \%$ of the total joint-stock capital. ${ }^{32}$ The major investments of

${ }^{20}$ The cstimatc is bascd on Lietuvos statistikos metraštis (LSM), vol. 12, 1939, 172, 174, 180-182, 185; Lietuvos pramone ikisocialistiniu laikotarpiu. Vilnius, 1976, 394-402; Step. Stankus. Mišrinc įmoné, Ekonomika, no. 1)17), 1939, 19-43; Lietuvos ūkio paskutinis dešimtmetis: Prekybos, pramonès ir amatų rūmų kojunktūrinè ūkio apžvalga. Kaunas, 1938, 34-56; Vyriausybès žinios, no 573 (part 2), 1939, 20; no. 579 (part 2) p. 18; no. 580 (part 2), p. 18; no. 700, 1940 (Pricdai), p. 342; no. 706 (Pricdai), p. 448.

${ }^{27}$ Lietuvos ükio paskutinis dešimtmetis, p. 99-105.

${ }^{28}$ LSM, vol. 12, 1939, 283, 285; Lietuvos ūkio paskutinis dešimtmetis, p. 105-110; Mažoji lietuviškoji tarybine enciklopedija, vol. 2, p. 911. Sometimes larger figures could be found - 34 per cent of the commodity turnover are attributed to cooperatives and their unions, and together with Maistas and Lietuvos cukrus this turnover is raised to 50 per cent; see A. Martinaitis. Juozas Tūbclis - ūkių organizatorius. Lietuvos $\bar{u} k i s$, no. 14, 1991, 31.

${ }^{29}$ S. Stankus. Mišrinc įmonć. Ekonomika, no 1(17), 1939, 28-29.

${ }^{30} \mathrm{M}$. Lipčius. Nepaprastų valstybès išlaidų vaidmuo tautos ūkyje. Tautos ūkis, no. 9 , $1940,184$.

${ }^{31} \mathrm{P}$. Tamošaitis. Akcinćs bendrovés 1939 m. Tautos ūkis, no. 21-22, 1940, 419.

${ }^{32}$ The data, presented by Pr. Tamošaitis, are slightly different: on 1 January 1940 the state treasury had shares in 21 joint-stock companies (including five Klaipèda companies) and their total value was 78,900,000 It. In Lithuania (cxcepting the regions of Vilnius and Klaipeda) the state possessed 36.1 per cent of the capital of all the companies. See: ibid. 420 . 
the state capital were made in the sphere of credit $^{33}$ and food processing industry. ${ }^{34}$

Ideas of cooperation were persistently advocated throughout the entire period of independence of the country between the wars. Cooperation was considered one of the most effective ways for realizing various economic programmes. The Nationalists and their adherents vigorously maintained that namely cooperation would enable the national bourgeoisie to accumulate larger amounts of capital. In the late 1930s hundreds of thousands were members of cooperative societies. This movement changed the character of the country's economy the development of agriculture from plant-growing to cattle-breeding, the rise of the food-processing industry and a quite effectively functioning export.

The cooperative joint-stock company Lietūkis mainly exported grain and other agricultural produce, in which Maistas, Pienocentras or Lietuvos cukrus did not deal. Lietūkis imported the majority of the products necessary for agriculture: fertilizers, agricultural machines and equipment, salt, oil products, etc., purchased and sold grain, flax, eggs in the internal and foreign markets, sold fertilizers, agricultural machines and implements, selective seeds and thoroughbred animals; it also organized dairy societies and built grain-elevators, mills, etc.

The union of cooperative societies, Pienocentras, organized the production and export of butter and the sale of dairy products in the internal market. It was also engaged in the export of eggs, and in the late thirties - in fruit processing and export. In 1939 Pienocentras had 185 dairies, producing cheese and butter. It also bought eggs for export, built a juice factory and several fruit refrigeration store-houses.

Maistas, regulated by cooperative organizations, developed pigbreeding and the production of bacon; it also controlled cattle purchase, meat processing and export. ${ }^{35}$

${ }^{33}$ Threc joint-stock banks - Lictuvos bankas, Žcmés bankas and Kooperacijos bankas - whose joint-stock capital made up 63.2 per cent of mixed and $29.4 \%$ of the capital of all Lithuanian joint-stock companies. On 1 February 1940 the sharc capital of these banks was $65,000,000$ It., constituting respectively 61.4 per cent of the capital of the mixed and $31.6 \%$ of all Lithuanian joint-stock companies. Scc: K. Sruoga. Lictuvos įmoness, kuriose dalyvauja valstybć, p. 919; M. Lipčius. Nepaprastų valstybés išlaidų vaidmuo tautos ūkyjc. Tautos ükis, no. 9, 1940, 184.

${ }^{34}$ Joint-stock companics Maistas and Lictuvos cukrus, whose sharc capital was $16,750,000)$ lt. at the end of $1937(7.6 \%$ of the total share capital in Lithuania in 1937 and as much as $8.15 \%$ at the beginning of 1940); scc: K. Sruoga. Lietuvos imonés, kuriose dalyvauja valstybc், p. 919; M. Lipčius. Ncpaprastų valstybés išlaidų vaidmuo tautos ūkyjc. Tautos ükis, no. 9, 1940, 184).

${ }^{35} \mathrm{~V}$. Pauliukonis. Koopcracijos ịaugimas ị valstybinio monopolistinio kapitalo sistemą buržuazinćjc Lictuvojc. Ekonomika, vol. 2, 1962, 108; A. Martinaitis. Juozas Tūbclis - ūkiụ organizatorius. Lietuvos ükis, no. 14, 1991, 29-31. 
Pienocentras, Lietūkis and Maistas were closely associated with the state structures. Not a single of these three major Lithuanian economic organizations could function without the support and attention of the government. In 1939 the export of Pienocentras made up 28\% of the entire Lithuanian export; the share of Lietūkis was correspondingly $15 \%$. Together with Maistas the export of the 'big three' constituted $77 \%$ of the total export of the country. ${ }^{36}$

The formation of such powerful monopolies of production and commerce (in the first place in the sphere of export and import) and the support they received from the government not only caused the resistance of their rivals, but also the doubts of some specialists and government officials about the rationality of such a tendency in the conditions of Lithuania. The critics maintained that the state control of these great economic amalgamations was only fictitious. In due course it became quite obvious that the government itself had to follow their dictate, and in future it could endanger the policy of the state. ${ }^{37}$

Thus a sort of paradoxical situation developed. In its efforts to effectively control national economy, the government established large economic structures to organize production and commerce. Using government capital and enjoying the support of state institutions, these influential structures successfully developed their activity and looked for new spheres They coordinated their interests to avoid mutual competition and set up branch structures, there by increasing their influence in those spheres, which up to that time had been the preserve of private business. ${ }^{38}$ At the same time, those who considered these tendencies undesirable and even detrimental to the state, continued requiring greater state control and stricter economy management on the part of the government.

${ }^{36}$ LSM, vol. 12, 1939, 281, 285; Žemés ūkio ministerijos metraštis. XX, Kaunas, 1938 , $11-15,63-64$.

${ }^{37}$ Ūkiškos centralizacijos problema. Tautos ūkis, vol. 17, 1940, 339.

${ }^{38}$ One of the most cvident instances of this tendency was the meeting of 4 January 1939, at which the representativcs of Lictūkis, Picnocentras, Sodyba and the Department of Agriculture of the Ministry of Agriculture decided to divide among themselves the spheres of activity and to re-arrange the purchase, processing and export of secds, berrics and fruits (LCVA, f. 1064, ap. 3, b. 54, 1. 372-377). Thus the society Seklininkas, actually, was 'swallowed', and Sodyba was re-organized into a joint-stock company in spite of the protest of the mecting of its members. Sec: minister of agriculture Jurgis Krikščiūnas' letter of 6 July 1939 to the minister of finances Jonas Sutkus concerning centralizing the export of cherrics and black currants. LCVA, f. 1064, ap. 3, b. 54, I. 289; the 4 July 1939 letter of the board of the union Sodyba of the societies of the Lithuanian agricultural minor branches and special cultures to the minister of finances J. Sutkus concerning the fruit export. LCVA, f. 1064, ap. 3, b. 54, 1. 29()-291; the 18 April 1939 letter of the gencral mecting (of 14 April 1939) of the union Sodyba of the societies of the Lithuanian agricultural minor branches and special cultures to the minister of agriculture J. Krikščiunas to the effect not to change the status of the co-opcrative socicty Sodyba. LCVA, f. 1064, ap. 3, b. 54, 1. 393). 
In the period between the two world wars the idea of the society of 'civilized co-operators' was cherished by many Lithuanian specialists, in particular by farmers. Algirdas J. Greimas, maintaining that the progress of national economy was achieved due to the efforts of 'largely socialist' proponents of co-operation, meant Jonas Aleksa, Jurgis Krikščiūnas, Jonas Kriščiūnas, Juozas Tubelis and many other specialists of Lithuanian national economy. ${ }^{39}$

In 1939-1940, when attention was focused on the centralization of those spheres of foreign trade, which up to that time had been in the hands of private entrepreneurs, and when new monopolistic centres were formed, the competitive rivalry intensified between those who more or less could be considered adherents of cooperation and their enemies, although in actual fact it was a clash of competitors. In this respect the regulation of the flax trade is worth closer examination. Various unexpected turns and the outcome of the struggle vividly reveal the topicalities of the economic policy in the last years of Lithuania's independence.

In independent Lithuania not much attention was paid to flax growing, although in the early twenties flax fibre and seed export was quite vigorously, because prices were rather high. In 1930 and 1931 prices fell and flax crops decreased. At the end of 1934 a law on the control of flax fibre and tow was passed introducing the sorting and control of the exported products. When the competitive ability of Lithuanian flax strengthened, farmers again began to pay greater attention to flax growing. In 1935-1938 the income from the recovering flax production and export was $107,500,00 \mathrm{lt}$. or $13.71 \%$ of the total national export income of $784,300,000$ It. $^{40}$

Flax growing was one of the main branches of agriculture which for a long time had not been covered by any form of co-operation. Greater interest in its re-organization was shown only in the mid-thirties. In February 1939 the Seimas commission for farming affairs stated that in Lithuania the areas under flax were too small, the quality of flax fibre for export was poor and in foreign markets Lithuanian flax was being assigned a low rating. Relatively simple organizational measures could improve the situation and raise the value of Lithuanian flax by $10 \%$ to $15 \%$ in the international market. Under the aegis of the state a joint-share or co-operative company should be entrusted with a task of flax trade. ${ }^{41}$

${ }^{39}$ A. J. Grcimas. Antanas Smctona ir kas toliau. Kultüros barai, no. 5, 1989, 57.

"The cstimatc is bascd on Žemés ükio metraštis. XX, Kaunas, 1938, 11-12; LSM, vol. $11,1938,252,256$.

${ }^{4}$ The 23 February 1939 letter of the Seimas commission to the Council of Ministers conccrning the re-organization of flax production. LCVA, f. 923, ap. 1, b. 1063, 1. 21, 23. 
On 4 July 1939, the Council of Ministers set up a commission for the restructuring of flax production..$^{42}$ The commission investigated the production and trade aspects and compared them with the situation in the countries of the 'next-door neighbours.' The members were not unanimous in their recommendations. Thus two projects on the reorganization of flax production and trade were proposed: those of the chairman of the commission, J. Tubelis, and of the director of the Agricultural Department of the Ministry of Agriculture, Vladas Tiškus.

According to both projects, flax production was to be organized in the way similar to dairy-farming or pig-breeding, and decisive measures should be taken to develop flax production and export. ${ }^{43}$ 'Maximum centralization'44 should be the objective of flax trade (purchase - processing - export), said the project of the commission.

When the war broke out, the demand for flax as a strategic material increased sharply. On 20 October 1939 the Council of Ministers decided (1) to centralize flax purchase and processing for export, (2) to commission the co-operatives to perform those tasks, (3) to entrust the control of flax export to the Ministry of Agriculture. ${ }^{45}$

After the release of this resolution the Ministry of Agriculture set up to cooperative union, Linas, authorizing it to deal with all the problems of flax growing and commerce. On the basis of the 28 November 1939 resolution of the Minister of Finances the Chief Controller of Flax and Tow in January 1940 informed all the private dealers and exporters of flax to end the purchase and export of flax by 1 May 1940.46

Flax dealers, however, did not give up. In January 1940, the member of the Seimas Gen. Julius Čaplikas, representing the jointstock company Linu eksportas, handed the prime minister, Merkys, a memorandum to the effect that Linas was laying claims to a monopoly in flax trade and on the orders of the Minister of Finances private companies had to cease functioning by May 11940 . The disappearan-

${ }^{42}$ The 4 July 1939 minutes of the sitting of the Council of Ministers. LCVA, f. 923, ap. 1, b. $1080,1.122$.

${ }^{43}$ The project of the plan for the reconstruction of flax production, on 11 September 1939 submitted to the Council of Ministers by V. Tiškus, director of the Agricultural Department of the Ministry of Agriculture and a member of the commission of the Council of Ministers on the reorganization of flax growing. LCVA, f. 923, ap. 1, b. 1064, I. 183-186; the plan for the investigation of the re-organization of flax growing in Lithuania, submitted to the Council of Ministers on 30 August 1939 by the commission of the Council of Ministers on the re-organization of flax production. LCVA, f. 923, ap. 1, b. 1064, 1. 187-188b.

${ }^{44}$ The plan for the investigation of the re-organization of flax growing in Lithuania, submitted to the Council of Ministers on 30 August 1939 by the commission of the Council of Ministers on the re-organization of flax production. LCVA, f. 923, ap. 1, b. 1064, I. 188.

${ }^{4}$.T The 20 October 1939 minutes of the sitting of the Council of Ministers. LCVA, f. 923 , ap. 1 , b. $1080,1.195$.

${ }^{4}$ The 20 April 1940 letter of the board of the cooperative union Linas to the Council of Ministers on the re-organization of flax cxport. LCVA, f. 923, ap. 1, b. 1550, 1. 151. 
ce of competition would be detrimental to the economic interests of the state. ${ }^{47}$

In April 1940 private businessmen again applied to A. Merkys, explaining the advantages of competition and the role of Linu eksportas in the economy of the country. The prime minister was asked not to deprive private businessmen of the right of flax export and import. The suspension of the company's activity 'at this time would incur great material losses for national economy'. ${ }^{48}$

The démarche was effective. The Ministry of Finances endorsed the charter of Linu eksportas and allowed it to continue the flax export after 1 May 1940. During his visit to the minister of finances, E. Galvanauskas, on 16 April, the chairman of the cooperative union, J. Krikščiūnas, learned that there appeared doubts as to the full transfer of purchase and export transactions to Linas. The board of Linas, in its turn, issued a memorandum, requiring the observation of the Council of Ministers, decision of November 281939 which forbade private dealers and their unions purchasing and exporting flax. ${ }^{49}$

The debate in the Seimas was extremely stormy, during discussion of draft of the law 'On Managing National Economy in the Extraordinary Situation.' The member of the Seimas A. Andrašiūnas declared that co-operation was in jeopardy, while the war showed that but for cooperation Lithuania's economy would have suffered much greater losses, because foreign capital was forcing its way into the country 'with the connivance of some government officials.' The foreign capital is threatfully occupying 'our positions, our places. $<\ldots>$. If the uncontrollable private capital dominated everywhere, life would be hard'.$^{50}$ Jonas Tallat-Kelpša deplored the tendency to restrict the activity of the co-operatives. ${ }^{51}$

The advantages of co-operation are ostensible, retorted Gen. J. Čaplikas. Co-operation, often taking the form of bureaucratic state institutions, does not fairly compete with private business. Both bu-

${ }^{47}$ The 28 January 1940 memorandum of J. Čaplikas, representing the joint-stock company Linu cksportas, to the prime minister on flax cxport. LCVA, f. 923, ap. 1, b. 1550, l. 157-158.

${ }^{45}$ The 12 April 1940 memorandum of the joint-stock company Linų eksportas to the prime minister on flax cxport. LCVA, f. 923, ap. 1, b. 1550, 1. 154-155.

"The 20) April 1940 letter of the board of the co-operative union Linas to the Council of Ministers of flax cxport re-organization. LCVA, f. 923, ap. 1, b. 1550, 1. 151-153.

${ }^{5}$ 'The member of the Scimas A. Andrašiūnas' specch at the Seimas sitting of 5 April 1940 (the 8 th ordinary scssion, sitting no. 178), discussing the draft of the law 'On Managing National Economy in the Extraordinary Situation,' presented by the minister of finances E. Galvanauskas. LCVA, f. 923, ap. 1, b. 1114, 1. 583-584.

${ }^{5}$ The member of the Scimas and senior director of Maistas J. Tallat-Kelpša's specch on 20 April 1940 at the 6th extraordinary session of the Scimas (sitting no. 183/34), discussing the law of the statc budget of 1940. LCVA, f. 923, ap. 1, b. 1114, 1. 832. 
reaucrats and private businessmen live at the expense of the farmers, who must be satisfied with a lesser share. ${ }^{52}$

E. Galvanauskas rejected all the criticisms of the alleged intention of the government to suppress the co-operative organizations. Formulating the essence of the economic policy of the government he added that it was his wish that the organizations, financed by the Treasury 'should execute the policy of the government, and not of their own'. 53

\section{The Industrialization of Lithuania:}

\section{New Aspects of the Old Problem}

In the 1930s Lithuania's industrialization was much talked about, and in that connection great attention was also paid to the problem of autarky. Already in the period of the great economic crisis and depression in various Western European countries, a tendency had appeared to support their national economies and to make them less dependent on foreign countries. Autarkic tendencies were overwhelmingly evident in the economic policies of all states. Prohibitive custom duties, introduction of import and export quotas and of the licence system and the restriction of foreign currency transactions meant that "the principle of the greatest favour in international trade remained only on paper'. Lithuania also had to abandon the liberal policy of commerce and introduce import regulation. The licensing system enabled the government 'not only to keep the import at the necessary level, but also offered a chance in the search for new markets ...'54

Thus, there appeared proponents of economic self-sufficiency in Lithuania, too. True, here there were no adherents of absolute autarky. ${ }^{55}$ All discussions mainly dealt with the development of national industry, in other words, with Lithuania's industrialization. There were good reasons to consider that only the country's industrialization could lead to autarkically conditioned economic advantages - the minimal and rational import.

${ }^{52}$ The member of the Scimas J. Čaplikas' specch at the Scimas sitting of 5 April 1940 (the 8th ordinary session, sitting no. 178), discussing the draft of the law 'On Managing National Economy in the Extraordinary Situation,' presented by the minister of finances E. Galvanauskas. LCVA, f. 923, ap. 1, b. 1114, 1. 585-586.

${ }^{3}$ The concluding speech of the minister of finances E. Galvanauskas at the Seimas sitting of 5 April 1940 (the 8th ordinary session, sitting no. 178), discussing the draft of the law 'On Managing National Economy in the Extraordinary Situation,' presented by the minister himself. ibid. 1. 610.

${ }^{54}$ V. Mačys. Kaip mūsų vyriausybè kovoja su krizc. Tautos ūkis, no. 11, 1935, 298.

${ }_{55}^{5}$ Valdas Pruskus writes about bitter disputes between J. Krikščiūnas, allegedly categorically supporting the idca of autarky, and Albertas Tarulis, arguing that total autarky was inconccivablc in Lithuania. Scc: V. Pruskus. Tautos ūkio idçjų ir vadybos raiška tarpukario metais (II). Lietuvos ükis, no. 10, 1991, 36. The disputes did take place, however, neither the former maintained that absolute autarky was feasible in Lithuania, nor the latter stated that the country should not strive for greater cconomic frecdom. 
The arguments of the adherents of Lithuania's industrialization were the following: (1) industrial investment generates quicker profit than agricultural investment; (2) industrial growth facilitates the purchasing capacity of the population, thus stimulating the development of trade; (3) the rise of the population's income leads to the increase of the budget, capital accumulation and to greater attention to culture, social welfare and the defence of the country.

In the opinion of Galvanauskas and like-minded colleagues, industrialization needed to be tackled without delay because only a very small part of the population was engaged in industry, and extensive agriculture could not offer decent living conditions for such large numbers of the people in the countryside. The annual increase of the population of about 20,000 to 25,000 also presented a problem (they could neither find jobs nor emigrate). There was a surplus of food products, although the consumption level throughout the country was not high. Furthermore, Lithuania to a very great degree depended on industrial countries, which used to buy cheaply Lithuanian agricultural produce and fix high prices for their industrial goods.

The opponents of rapid industrialization argued that previously the priorities given to the development of Lithuanian industry often resulted in the rise of prices and poorer quality of domestic products in comparison with imported ones. In general, the government, the president Antanas Smetona and the majority of the specialists tried to take a middle way, in principle being concerned with the concept of national autarky. ${ }^{56}$

The economist Albertas Tarulis wrote that for Lithuania autarkic policy was its industrialization. In that sphere obvious progress had been made in some spheres of industry, such as textiles, clothing, paper, sugar refining, producing for the home market and dairy and meat processing, producing mainly for export. That led to the increase in the number of people, employed in industrial enterprises, their concentration, and to the changes in the structure of Lithuanian export and import. The obstacles that prevented the development of industrialization were the increasing impecuniosity of the population in the first half of the thirties, the loss of some foreign markets and the fall of the prices of the exported agricultural produce. The basis of further industrialization should have been the rational satisfaction of the internal demand and the increase of agricultural produce, suitable for export. The export of semi-finished products should not be relied upon. In future industrialization should be 'no more spontaneous, but planned, taking into account the power resources, raw materials, the presence of specialists and introducing correctives into the economic policy; ... pursuing the autarkic policy of industrialization, sacrificing ne-

${ }^{56} \mathrm{~V}$. Pruskus. Tautos ūkio idejjų ir vadybos raiška tarpukario metais (II). Lietuvos ükis, no. 10, 1991, 36. 
ither export, nor import, but properly regulating and developing both aspects' ${ }^{57}$

The government was aware that Lithuania could not be isolated from the international market and that artificial restriction of foreign trade would not be reasonable. On the other hand, nobody doubted the need of lesser dependence on other countries. Therefore in the thirties serious attempts were made to develop both the food production for export and other branches of (light) industry to meet the internal demand. Their expansion was encouraged by corresponding custom duties, credits and direct investment of the state capital.

In the late 1930s the minister of finance, Julius Indrišiūnas, called for a more energetic regulation of the national industrial development and proposed to set up a special institution to deal with industrialization. ${ }^{58}$ On his initiative the project of setting up the Ministry of Industry and Commerce was launched and the law on industry was being prepared..$^{59}$

Later on, in 1939, the minister of finance, J. Sutkus, arguing in favour of the Department of Industry and Commerce at the Ministry of Finance, indicated that the primary task of that department would be 'to take care of Lithuania's industrialization, which has become the problem of utmost importance of the country's national economy'. ${ }^{60}$

In May 1940 the prime minister, Merkys, said that 'the government is extremely concerned with the expansion of national industry. The task of the new Bank of Industry is to provide the funds, necessary for the development of industry'. ${ }^{61}$

Despite Lithuania's tragic international position and grave economic situation the end of 1939 and the beginning of 1940 was the period of substantial constructions and still greater plans. The construction of a sugar refinery (the third in the country) in Panevéžys was finished in 1940. The construction of the sea-port of Šventoji was going on and even its coming into operation was expected. ${ }^{62}$ Elektra, a joint-stock company in Rekyva at Šiauliai, nearly completed the

${ }^{57}$ A. Tarulis. Autarkinćs tendencijos Lictuvos ūkyje. Tautos ūkis, no. 5, 1936, 132.

${ }^{58}$ Aktualicji mūsụ ūkio reikalai. A talk with the acting minister of finances J. Indrišiūnas about industrial and other urgent problems of cconomy. Tautos ükis, no. 1, 1937, 5.

${ }^{59} \mathrm{~V}$. Mačys. Stcigtina pramonćs ir prckybos ministcrija. Tautos ükis, no. 46, 1939, 851; A. B. Dèl Finansų ministcrijos reorganizacijos. Tautos ūkis, no. 49, 1939, 911; Dz. Budrys. Pramonć 1939 metais. Ekonomika, no. 2, 1939, 125.

${ }^{6}$ The minister of finances J. Sutkus' cxplanatory note of (May or April?) 1939 to the Council of Ministers concerning the setting up of the Department of Industry and Commerce at the Ministry of Finances. LCVA, f. 923, ap. 1, b. 1061, 1. 443.

${ }^{61}$ The prime minister A. Merkys' specch at the 7 May mecting of the Chamber of Commcrcc, Industry and Handicrafts. Tautos ükis, no. 18, 1940, 360.

${ }^{62}$ The draft estimate of the Ministry of Communications, presented by its minister $\mathrm{K}$ Germanas to the Council of Ministers on 23 August 1939. LCVA, f. 923, ap. 1, b. 1118, 1. 112. 
construction of the power plant to supply electricity to the districts of Šiauliai and Panevéžys and a cement factory to be built in Skirsnemune. ${ }^{6.3}$

There were more large-scale construction plans. A water way, connecting Kaunas, Vilnius, Klaipeda, Kèdainiai and Ukmergé, was proposed. ${ }^{64}$ After the return of Vilnius to Lithuania at the end of 1939 and with the appearance of the common frontier with Russia, the Lithuanian government forecast the Soviet need for transit through Lithuania to the West. After an analysis of the possible transport routes the traffic capacity of the Šauliai-Kretinga railway was found insufficient. Therefore the construction of a new railway from Kazlu Rūda through Sakiai to the coast of the Baltic Sea was started without delay. ${ }^{6.5}$

The central issue of that time was electrification of the country along planned lines. This objective was formulated by the government quite comprehensively: (1) to provide the whole country with cheap electricity, accessible to the wider strata of society; (2) to unify the conditions of power supply irrespective of the distance between the locality of the user and the power plant; (3) to use all the resources of the country suitable for the production of electricity; (4) to coordinate power production with the needs of the entire national economy.

A special committee - the Committee of Power - was set up for the preparation of a plan and for the studies related to its further elaboration and realization. The outline of the plan was drawn up by the spring of 1940. Elektra, a special company, was established for bringing the plan into effect. ${ }^{66}$ In the first five years (1939-1943) the following major constructions were planned: to finish the construction of the Rekyva complex, to build the power plant of Turniškes and the energy transmission line between Vilnius and Kaunas, to carry out preliminary work for the use of the water power of the river Nemunas, to build the Minija power plant and the transmission lines between Plungè, Kretinga, Palanga and Šventoji. Electrification costs were estimated at about 500,000,000 lt. and foreign loans were planned, as 'so much free capital could not be found in the country'. ${ }^{67}$

${ }^{6.3}$ The minister of communications K. Germanas' letter of 9 October 1939 to the Council of Ministers on the request of Elektra to rent a part of the Rekyva peatbog. LCVA, f. 923 , ap. 1, b. 1064 , 1. 18; the minister of communications J. Masiliūnas' answer to a question of a number of the members of the Scimas concerning Lithuania's electrification. The 28 May 1940 sitting (no. 192/33) of the 6th extraordinary scssion of the Seimas. LCVA, f. 923 , ap. 1 , b. 1114 , I. $771-772$.

${ }^{64}$ Explanatory letter concerning the structure of the Board of Waters of the Ministry of Communications. LCVA, f. 923, ap. 1, b. 1118, 1.115.

${ }^{65}$ The construction was interrupted in the summer of 1940. Scc: A. Gulbinskas. Transporto victa rinkos sistemojc. Lietuvos ükis, no. 15, 1991, 13.

${ }^{66}$ The answer of the minister of communications J. Masiliūnas to the question of a group of the members of the Scimas conccrning Lithuania's clectrification. The 6th cxtraordinary scssion of the Scimas, the 28 May 1940 sitting no 192/33. LCVA, f. 923, ap. 1, b. $1114,1.771$.

${ }^{67}$ Ibid., 1. 772. 
In 1940 attention was focused on the construction of the hydroelectric station of Turniškès. Its building was started by the Poles and work was continued according to their designs. However, the designs had not been finished, and the construction had to be interrupted temporarily until the preparations of the necessary blueprints. A contract was signed with a Swedish firm for the final designs. Eventually the cost of the construction became known. ${ }^{68}$ By the end of 1939, $1,500,000 \mathrm{lt}$. had been spent for the construction of the power plant of Turniškès, and preliminarily the total cost was estimated at about $18,000,000-20,000,000 \mathrm{lt}$. In the budget of 1940, 4,300,000 lt. were allotted for that construction. ${ }^{(9)}$

Industrial investments aroused the concern, even dissatisfaction of some economists, in particular, of the agriculturists. The member of the Seimas A. Andrašiunnas criticised the project of the 1940 budget for its insufficient attention to agriculture (of the total sum of $432,000,000$ lt. only 40,000,000 lt. were assigned to agriculture). ${ }^{70}$ His standpoint was maintained by the deputy chairman of the Seimas J. Indrišiunas, indicating possible negative social consequences of the industrial development. ${ }^{71} \mathrm{~S}$. Jakubauskas voiced his apprehension about the increased purchase of shares to finance industry, transport and other branches of economy. ${ }^{72}$

Expressing his attitude to those remarks, E. Galvanauskas maintained that in its agricultural policy the government was taking measures to raise agriculture to a higher level - from plant-growing to animal-husbandry and dairy-farming. Attempts were made to intensify agriculture, to organize the manufacture and sale of the produce. The realization of those objectives would be possible if the country had an adequately developed industry. ${ }^{73}$

\section{State Regulation of Economic Relations}

At the beginning of World War II the law 'On Managing National Economy in the Extraordinary Situation' was passed. The fi-

${ }^{68}$ Ibid.

${ }^{69}$ Ibid., 1. 744; R. Žcpkaitc. Vilniaus istorijos atkarpa. p. 95

${ }^{70}$ The specch of the member of the Scimas A. Andrašiūnas on 20 April 1940 at the 6th extraordinary session of the Scimas (sitting no. 183/34), debating the law of the 1940 state budgct. LCVA, f. 923, ap. 1, b. 1114, 1. 843.

${ }^{71}$ The specch of the first deputy chairman of the Scimas J. Indrišiūnas on 20 April 1940 at the 6th extraordinary session of the Scimas (sitting no. 183/34), discussing the law of 1940 statc budget. LCVA f. 923, ap. 1, b. 1114, 1. 846-847.

${ }^{72}$ The specch of S. Jakubauskas, director of the Chamber of Agriculture and member of the Scimas, on 20 April 1940 at the 6th cxtraordinary session of the Scimas (sitting no. 183/34), discussing the law of the 194() state budget. LCVA, f. 923, ap. 1, b. 1114, 1. 825 826.

${ }^{73}$ The concluding spech of the minister of finances E. Galvanauskas on 20 April 1940 at the 6 th cxtraordinary session of the Scimas (sitting no. 183/34), debating the law of the 1940 state budget. LCVA, f. 923 , ap. 1, b. 1114, I. 864-865. 
nance minister was empowered to regulate exports, imports, production and commerce. The penalties for violating the decisions of the minister could be as severe as 100,000 lt. or a jail term of six months. During a buying panic basic goods and foodstuffs could be sold only at the usual prices to the permanent customers - that was the instruction issued by the Price Controller. Merchants were forbidden to raise prices and pile up goods. The sale of kerosene and petrol was restricted only the enterprises, offices and their transport were given police permits to acquire fuel. ${ }^{74}$

On 7 October on the basis of the new law, the minister of finance, J. Sutkus, issued a new order, relating to the setting-up of enterprise unions. The order indicated that "mandatory unions of enterprises shall be established to coordinate the activity of enterprises with the interests of the state.' The aim of the unions was to perform the tasks, imposed by the ministry, of producing, importing, exporting, storing, distributing, selling goods and materials, and fixing prices. ${ }^{75}$ By May 1940, 18 unions of that type were established. ${ }^{76}$

E. Galvanauskas, having replaced J. Sutkus in the post of the finance minister, in the autumn of 1939 paid meticulous attention to the control of foreign trade. He continued his predecessor's policy of centralizing foreign trade and adhered to the opinion that a special centre was necessary for each major item (or a group of items) of export or import. What all that meant in practice was seen in the reorganization of flax trade.

Formally the activity of individual merchants was not forbidden, practically, however, it was severely restricted. E. Galvanauskas and others maintained that the centralized foreign commerce was not only easier to regulate, but also to sponsor. Free competition was to be tolerated only in home trade; the rivalry of Lithuanian businessmen abroad was not only useless, but also harmful. ${ }^{77}$

Several important organizational reforms were carried out in the sphere of industry regulation. The recommended separate ministry of commerce and industry was not set up, however, the Department

${ }^{44}$ Vyriausybès žinios, no. 661, 1939, 578; Vyriausybe kapitalo tarnyboje: Tautininkų socialine ekonomine politika Lietuvoje: 1927-1940. Vilnius, 1984, 41 (further on - Vyriausybe kapitalo tarnyboje).

${ }^{75}$ Vyriausybe kapitalo tarnyboje, p. 68-69.

${ }^{76}$ Posćdžiavo Prck|ybos], pram|onès] ir amatų rūmai. Lietuvos žinios, 8 May 1940. (The following werc the enterprisc unions: of Lcather and Footwcar, of Fur Industry and Import, of Brickworks, of Brewcries, of Solid Fucl, of the Importers of Building Materials, of Commcrcial Mills, of Distilleries, of Textiles Importers, of Metal Industries and Import, of Paper and Cardboard Factorics, of Flax and Cotton Industrics and of some other unions).

${ }^{77}$ Ccntralizuojama užsicnio prckyba: pasikalbçjimas su Finansų ministru inž. E. Galvanausku. Tautos ūkis, no. 50, 1939, 931-932. 
of Commerce and Industry was established at the Ministry of Finances. Its task was to regulate the issues of industry and home trade. ${ }^{78}$

On 7 May 1940 a new 'Law on Managing National Economy in the Extraordinary Situation,' was passed. This enabled the government to manage the activity of industrial enterprises still more effectively, to plan and control their production and to supervise home and foreign trade. The finance minister was authorized to request the owners of enterprises, no more functioning for certain reasons, to renew or begin manufacture and, in case of disobedience, to sequestrate them. ${ }^{79}$

At the Seimas sitting on 5 April 1940, E. Galvanauskas stated that all possible steps are taken to protect national economy from external dangers and without delay react to various abnormalities, appearing in the home market in the present complicated economic circumstances. The finance minister was authorized to strengthen and regulate the country's productive forces and ensure that the essential vital demands of the population were satisfied - that was the reason why the minister was given such unrestricted powers. ${ }^{80}$

The finance minister had to establish enterprise organizations, to fix the terms of their functioning, to check and approve the plans of their activity and to control their realization. He had a right (a) to issue import and export licences for particular goods and to fix corresponding taxes, (b) to centralize and control the provision of national economy with essential commodities, (c) to prohibit the import and export of certain goods, (d) to coordinate the activities of foreign firms in the country and the representation of Lithuanian trade interests abroad, and (e) in cases of deficiency to regulate the distribution of locally produced and imported goods. ${ }^{81}$

The finance minister was also authorized (a) to fix the quotas of production and sale, (b) to distribute production quotas among factories, (c) to establish the quantity of materials and goods for storage and (d) to oblige the enterprises to have sufficient amounts of raw materials and means of production. ${ }^{82}$

${ }^{78}$ The minister of finances J. Sutkus' note to the Council of Ministers concerning the establishment of the Department of Industry and Commerce at the Ministry of Finances. LCVA, f. 923 , ap. 1, b. 1061, 1. 439.

${ }^{7}$ The finance minister E. Galvanauskas' specch at the Scimas sitting of 5 April 1940 (the 8th scssion, sitting no. 178), presenting the draft of the law 'On Managing National Economy in the Extraordinary Situation.' LCVA, f. 923, ap. 1, b. 1114, 1. 568.

${ }^{8}$ The finance minister of E. Galvanauskas' specch at the Scimas sitting of 5 April 1940 (the 8th scssion, sitting no. 178), presenting the draft of the law 'Managing National Economy in the Extraordinary Situation.' LCVA, f. 923, ap. 1, b. 1114, 1. 568.

${ }^{81}$ Ibid., p. 1. 568-571.

${ }^{82}$ Ibid., 1. 572-573. In E. Galvanauskas words, 'In respect to some means of production, the conditions of clcaring arc mcant as a possibility for our enterprises to acquirc more cfficicnt and up-to-datc mcans of production'. 
The new law enabled the minister to exert greater influence in regulating the economy of the country. ${ }^{83}$ Taken all in all, it was evident that at the beginning of the summer of 1940 attempts were being made to radically centralize Lithuanian economy.

${ }^{83}$ Ibid., I. 573-574. E. Galvanauskas: 'I would not say that all that is an end in itself, nevertheless, cveryday affairs have proved that such rights are necessary for the finance ministcr.' 